\section{Sex, racism and videotape}

\section{Washington}

A Canadian psychologist whose theories on the links between human intelligence, race and sexual appetite have drawn wide protest will have to teach most of his classes by videotape next term to avoid violent clashes with demonstrators.

The University of Western Ontario officials announced last month that Philippe Rushton, a tenured professor in the psychology department, will teach all his undergraduate courses "using a personalized system of instruction (PSI) format". What that means, the university said, is that Rushton will videotape a 90minute weekly lecture, which will then be available for viewing throughout the week at the convenience of his students.

Protesters, of whom the university expects hundreds, will find no class to disrupt or demonstrate outside.

Rushton has protested at the decision as an abridgement of his academic freedom, and has formally appealed against it. But university officials say that their decision was actually the only way to preserve that freedom. "We are expecting a concerted, highly organized protest on the first day of class [10 September]. We decided that we must protect [Rushton's] freedom to teach, and this was the way to do it", says university provost Thomas Collins.

Since Rushton's theories were first publicized in the press in 1989, he has been the focus of a storm of controversy. The premier of Ontario has publicly stated that Rushton's views are "morally offensive to the way Ontario thinks", and Rushton has been investigated by a special police force concerned with pornography and "hate literature" (its findings: "loony, but not criminal").

His most controversial theories revolve around his attempts to measure behavioural and physiological differences between races and to relate them to past evolutionary history. Rushton has compared more than 60 different variables including such factors as cranial capacity and genital size - and concluded that a continuum can be found, with Mongoloids at one end, Negroids at the other, and Caucasians somewhere in between. His work is partly supported by the Pioneer Fund, a New York-based private organization that has been widely attacked for funding research related to eugenics. Rushton's appearance on "Geraldo", a US television talk show, and massive press coverage in Canada have helped to stimulate calls for his dismissal and demonstrations outside his classrooms.

Last year, Rushton circulated a letter appealing for support from other researchers, which brought in over 40 letters, some of them from well-respected scientists. Although many disagreed with
Rushton's views, there was considerable support for his right to pursue his own ideas and protest over the "unsatisfactory" rating the university had given Rushton for his recent academic performance. (Three "unsatisfactory" ratings can lead to the dismissal of even a tenured professor.)

Until last month, the university and Rushton were negotiating a strategy for the new term to avoid more outbreaks of violence. Although tentative agreement had been reached on a plan to allow Rushton to teach in a portable classroom (which could be ringed by police and isolated from other classes) near the perimeter of the campus, negotiations broke down over Rushton's demands for security. "He said that if we had 300 demonstrators, we should provide 300 security guards. Obviously, we can't do that," says Collins. The university solution - videotape - has been received no better by Rushton, but outside support is proving difficult to muster.

The Canadian Association of University Teachers has asked a panel to address the issue, but executive director Donald Savage says that the requirement that professors videotape lessons is neither linprecedented nor necessarily a violation of academic freedom. In large introductory classes where classroom space is a concern, the practice is quite
REPRESENTATIVES of all eight countries with territory in the Arctic agreed last week to establish a new nongovernmental International Arctic Science Committee (IASC) to coordinate research in the

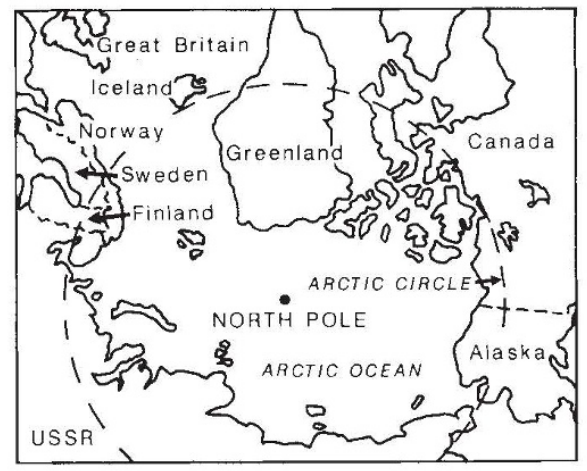

region. The agreement, signed at the remote scientific outpost at Resolute Bay, has been several years in the making and only became possible with the coming of perestroika.

The region is still ringed with radar early-warning stations, air bases (commanded on the western side from Thule

\section{Washington}

\section{Longest running reactor retires}

\section{London}

THE world's longest continuously operating nuclear reactor was shut down on 3 September. The Graphite Low Energy Experimental Pile (GLEEP) has been in service at the UK Atomic Energy Authority's Harwell laboratory for the past 43 years. Designed for the study of reactor physics, it demonstrated the stability of graphite-moderated gas-cooled reactors, which went on to form the backbone of Britain's nuclear electricity generating industry.

For most of its life, GLEEP ran at a fraction of its potential power, as a versatile research reactor, used for testing reactor materials and calibrating radiation monitors.

PeterAldhous

common at some universities, he notes.

The university faculty association has not taken a formal stand on the issue, preferring to wait for the conclusion of the university grievance process. Some other faculty members privately say that they are troubled by the university decision, but few have rallied to oppose it. "As unpalatable as I find this solution, it avoids the possibility of flashpoints of violence, and it ensures that we don't have to stop [Rushton's] classes," says psychology chairman Greg Moran.

Christopher Anderson

\title{
The cold war ends at Resolute Bay
}

in Greenland) and stations for submarines which operate under the ice pack.

Canada, Denmark, Finland, Iceland, Norway, Sweden, the United States and the Soviet Union now invite other countries with Arctic research programmes but without territory in the region to seek membership in IASC. The United Kingdom, France, Germany and Japan are thought likely to be the first to join.

The greatest advantage conferred by membership will be the opportunity to coordinate research and share resources in a region where logistical problems are often overwhelming. The Soviet Union has a large fleet of powerful ice breakers, Canada has several research ships and the United States has good satellite coverage of the area - put together, the whole should permit research programmes that are not now possible.

Research in the Arctic will become increasingly important as the first signs of global change appear. Greenhouse warming is expected to be greatest at the poles and to lead to changes in the sea ice cover and the melting of glaciers and ice sheets.

Alun Anderson 